Article

\title{
Approaches to Addressing Informal Settlement Problems: A Case Study of District 13 in the Kabul city, Afghanistan.
}

\section{Maqsood Rezayee ${ }^{1,}$ *, Gabriel Hoh Teck Ling ${ }^{2}$, and Siti Hajar Misnan ${ }^{3}$}

1 Department of Urban and Regional Planning, Faculty of Built Environment and Surveying, Universiti Teknologi Malaysia, Skudai, 81310 Johor Bahru, Johor, Malaysia

2 Department of Urban and Regional Planning, Faculty of Built Environment and surveying, Universiti Teknologi Malaysia, Skudai, 81310 Johor Bahru, Johor, Malaysia; Email: gabriel.ling@utm.my

3 Department of Urban and Regional Planning, Faculty of Built Environment and surveying, Universiti Teknologi Malaysia, Skudai, 81310 Johor Bahru, Johor, Malaysia; Email: shajar@utm.my

* Author to whom correspondence should be addressed; E-Mail: mqsoodrezay@yahoo.com; Tel: +93797328619

\begin{abstract}
Afghanistan witnessed rapid urbanization in recent decades due to the post-war recovery process. When the war ended in 2001 by fall of Taliban regime, most Afghans refugees returned to urban areas of Afghanistan, especially in Kabul city. Moreover, the rapid urbanization, migration from rural areas, and population growth impacted on Kabul city with the manifestation of informal settlement. The residents of informal settlements suffer social and economic exclusion from the benefit and opportunity of an urban environment. Furthermore, the residents of informal settlements experience disadvantages by geographical marginalization, shortage of basic infrastructure, improper governance framework, vulnerability into the effect of poor environment, and natural disasters. With all the above, the problems of informal settlements are considered enormous challenges for informal residents. Therefore, this paper aims to identify the proper approaches to addressing informal settlement problems in District 13 of Kabul city. To reach the aim of the research, the interview and questionnaires survey used as an instrument in data collection. Consequently, the finding of this paper indicates that through the resident's preferences, government capacity, and District 13 physical condition there are three approaches which can be implemented and adopted for improvement of informal settlement in District 13 of Kabul city, which is settlement upgrading as the first option, the land readjustment as the second option and urban redevelopment as the last option.
\end{abstract}

Keywords: Informal settlement, Sustainable Neighborhood, Approaches, District 13 of Kabul city Afghanistan. 


\section{Introduction}

The housing in the informal settlement does not comply with the planning and other regulation. Apart, informal settlements do not provide the opportunity and facility for the residents to have a proper and standard life. Therefore, the informal settlement is unplanned, has insecure property tenure, the neighborhoods are often lack of basic services, and infrastructure, and registration as part of the urban fabric [1,2].

Afghanistan witnessed rapid urbanization in recent decades due to the post-war recovery process. When the war ended in 2001 by the fall of Taliban regime, most Afghans refugees returned to urban areas of Afghanistan, especially in Kabul city. Moreover, the rapid urbanization, migration from rural areas, and population growth impacted on Kabul city with the manifestation of informal settlement [3].

In terms of Kabul city informal settlement refers to (a) the housing and settlements which built up in violation of the master plan of Kabul, (b) settlement which developed without meeting the formal requirement for access to the land [4].

Although the informal settlements provide a critical function in Kabul city, however, the informal settlements are not without problems [3]. The physical problems of informal settlements are enormous and severe challenges to informal residents in Kabul city. In Kabul city, the problems of informal settlements refer to lack of drainage system and sewage system, lack of solid waste management, unpaved and narrow streets, lack of open spaces, recreation and greenery, lack of water supply system, and pollution of underground water [5,6, 7]. Also, in most cases, the property right violated then, insecurity of land tenure is another challenge because the illegal land grabbing without official permission is a threat of eviction and displacement [8].

With all the above, residents of informal settlements suffer social, spatial, and economic exclusion from the benefit and opportunity of the urban environment. Besides, the residents of informal settlements experience disadvantages by geographical marginalization, shortage of basic infrastructure, improper governance framework, vulnerability into the effect of poor environment, and natural disaster [9]. Recent researches have been conducted to identify the problems of informal settlements and the factors behind the growth of informal settlements in Kabul city. However, based on the previous researches, it was found, there are not researches and studies to investigate the identification of approaches to addressing the problems of informal settlements. However, this research covers the content and the subject which missed similar previous research.

Therefore, this paper aims to investigate the identification of proper approaches according to the physical condition of informal settlement and preferences of residents for improvement of the informal settlement in District13 of Kabul city. Kabul Municipality Areas divided into 22 Districts informal settlement differs in size and other characteristics from District to Districts [10]. Every District of Kabul can be studied for this research. However, District 13 has been chosen for this research because the built environmental problems which have been posed by informal settlement in Districts 13 of Kabul city are most prominent and influential. 


\section{Approaches to Addressing the Problems of Informal Settlement}

There are many approaches to address the problems of informal settlement. These approaches are often referred to, core housing, provision of site-and-service, settlement upgrading, greenfield development, infill development, land readjustment, on-site redevelopment of informal settlement, and evacuation and relocation of informal settlement $[11,12,13]$.

Core housing refers to the provision of basic infrastructure for the dwellings with a minimum level of services. According to this approach, if finance becomes available, the housing should extend [11]. In addition, this approach includes the regulation of land tenure as well as the minimum provision of basic services, like the provision of water supply, sanitation, and some other services [11].

Provision of site-and-services refers to an approach in which the residents get the plots and the primary services such as the sanitation, water supply system, and paved roads, which also ensure the land property right [13]. This approach includes the provision of site and services which are leaving for the house owners to construct [13, 14].

Settlement upgrading refers to the provision of basic services such as water supply system, sewage system, and drainage system, paving the streets, and provision of public amenities in the informal settlements, and this approach ensures land tenure $(15,16,17)$. Based on this approach, houses are accepted as they had already built; however, in some cases, dwellings rebuilt is also acceptable. Settlement upgrading improves the informal settlement without the relocation and settlement clearance [18,19].

Based on the greenfield development approach, the undeveloped areas built as residential areas. According to this approach, all services provided within the housing units and involves the security of land tenure. Greenfield development mostly turns out on a large scale and includes thousands of plots [11,20].

Infill development in common language, associated with densification, and in terms of informal settlement refers to the development of vacant parcels within previously built areas. These areas are already served by public infrastructures, such as transportation, water, water supply system, and other utilities. On a large scale, the infill development is similar to greenfield development, but it has a distinct variation in which greenfield development requires much new infrastructure and basic services than the infill development [11]. In addition, infill development can also happen in a land with an excellent location in terms of job opportunities and transportation, not just in the residential areas. Indeed, infill development is building houses, business facilities, and public facilities on unused and underutilized land within existing urban areas. Moreover, infill development keeps resources where people live and allows rebuilding to occur [11,21].

On-site redevelopment of informal settlement targets the informal settlement where the housing conditions are highly deteriorated and unsafe. This approach includes complete replacement of the physical fabric through gradual demolition and in site construction of alternative housing. This approach respects the legal right of residents for alternative housing and the dependence of their livelihood on staying in the same location in the city [13,22].

The land readjustment is a technique based on the re-assembling of land parcels by a new layout plan together with the development of new urban infrastructures, by means of changing shapes and conditions of land parcels, and construction of public facilities to increase the utility of sites and improve the public facility $[23,24]$. The land readjustment 
technique combines several tools, including pooling of property rights, physical reorganization of land parcels, and preparation of a layout plan. All the tools mentioned above are used to provide planned urban areas and access to infrastructure. The area which is selected for a land readjustment project, their shapes, and conditions of sites within the project area, is going to be improved by combining, dividing, annexing, and replotting [23,24].

Evacuation and relocation of informal settlement is the last option after all feasible approaches. This approach does not only include the complete demolition, but it also addresses the relocation of the residents. In this approach, residents are not going to stay in the same location so that they will move to a new city or fringes zone of the city $[13,25]$.

\section{Methodology}

The research method for this paper is the empirical mix mode research method, which encompasses the qualitative and quantitative data collection based on primary data and secondary data. Prior to the field survey, in secondary data collection, the source from the local authority, government record, and other's written have been reviewed on a better understanding of the informal settlement problems and approaches for improvement of informal settlement. Besides, to know the thought and policy of the government toward informal settlement. Secondary data has been obtained through reviewing different books, Dissertation, Master Thesis, Ph.D. Thesis, Journals, Research Report, Government Constitution, Seminar Papers, Government Guideline, and Regulation on Registration of Urban Informal Properties.

Site observation is the first stage of primary data collection, site observation made to have a better understanding of informal settlement's physical condition, and problems of informal settlement accordingly to propose the proper approaches. The site observation being conducting from 4th January up to 15th February 2019 in different parts of the case study area District 13 of Kabul city. In site observation, the main focus was on evaluating the physical and built environmental condition of informal settlement, which includes the physical measurement of the streets, exploring the housing quality and condition, degree of public facilities, basic services, and infrastructure, open spaces, and greenery.

Following the site observation, the semi-structured interview has been used as an instrument in data collection. Based on the semi-structured interview the respondents need to answer preset open-ended questions $[25,26]$. The interview has been conducted to have a deep understanding of the approaches to addressing the problems of informal settlement. Besides, to have a clear view of the government policy toward informal settlement. The selection of interviewees was based on experience and skills in the urban planning field.

The interview has been conducted with officials from, Ministry of Urban Development and Land, Kabul Municipality, Capital Region Independent Development Authority (CRIDA), Directorate of District 13, JICA (Japan International Cooperation Agency), and Un-Habitat. From the Ministry of Development and Land, the interview has been conducted with the director of Urban Research and Development Center, director of Upgrading of Unplanned Settlement Directorate, and National Urban Advisor. From the Kabul Municipality, the interview has been conducted with the head and members of Land Readjustment and Urban Redevelopment Division Directorate of Design and Implementation of City Plan. Moreover, from the Capital Region Independence Development Authority (CRIDA), the interview has been conducted with the director of Technical Planning and 
members of the Upgrading and Renovation Program Division. From Directorate of District 13, the interview has been conducted with the director of the Directorate of District 13 and head of Engineering Division. An additional interview has been conducting with the members of the JICA Project Team (The Project for Development Service for Land Readjustment and Urban Redevelopment for Kabul Municipality). Moreover, the interview has been conducted with the members of Un-Habitat-Afghanistan. Table 1 shows the interviewee's position.

Table1. Interviewee's position.

\begin{tabular}{|c|c|c|c|}
\hline Number & Position & Name of the Agencies & Total \\
\hline 1 & National Urban Advisor & \multirow{3}{*}{$\begin{array}{l}\text { Ministry of Urban } \\
\text { Development and } \\
\text { Land }\end{array}$} & \multirow[t]{3}{*}{3} \\
\hline 2 & $\begin{array}{l}\text { Director of Upgrading of Unplanned } \\
\text { Settlement Directorate }\end{array}$ & & \\
\hline 3 & $\begin{array}{l}\text { Director of Urban Research and } \\
\text { Development Center }\end{array}$ & & \\
\hline 4 & $\begin{array}{l}\text { Head of Land Readjustment and Urban } \\
\text { Redevelopment Division }\end{array}$ & \multirow[t]{2}{*}{ Kabul Municipality } & \multirow[t]{2}{*}{4} \\
\hline 5 & $\begin{array}{l}3 \text { members of Land Readjustment and } \\
\text { Urban Redevelopment Division }\end{array}$ & & \\
\hline 6 & Director of Technical Planning & \multirow{3}{*}{$\begin{array}{l}\text { Capital Region } \\
\text { independent } \\
\text { Authority }\end{array}$} & \multirow[t]{3}{*}{8} \\
\hline 7 & $\begin{array}{l}\text { Head of Upgrading and Renovation } \\
\text { Program Division }\end{array}$ & & \\
\hline 9 & $\begin{array}{l}6 \text { members of Upgrading and Renovation } \\
\text { Program Division }\end{array}$ & & \\
\hline 10 & $\begin{array}{l}\text { Member of Japan International } \\
\text { Cooperation Agency Project Team }\end{array}$ & \multirow[t]{2}{*}{$\begin{array}{l}\text { Japan International } \\
\text { Cooperation Agency }\end{array}$} & \multirow[t]{2}{*}{2} \\
\hline 11 & $\begin{array}{l}\text { Member of Japan International } \\
\text { Cooperation Agency Project Team }\end{array}$ & & \\
\hline 12 & Head of District $13^{\text {th }}$ Division & \multirow{2}{*}{$\begin{array}{l}\text { Un-Habitat- } \\
\text { Afghanistan }\end{array}$} & \multirow[t]{2}{*}{3} \\
\hline 13 & 2 members of District 13 Division & & \\
\hline 14 & $\begin{array}{l}\text { Director of the Directorate of the District } \\
13\end{array}$ & \multirow[t]{2}{*}{$\begin{array}{l}\text { Directorate of District } \\
13\end{array}$} & \multirow[t]{2}{*}{2} \\
\hline 15 & Head of Engineering Division & & \\
\hline Total & & & 22 \\
\hline
\end{tabular}

Furthermore, survey questionnaires have been used as an instrument in data collection. The survey questionnaire has been conducted with 200 residents of District 13 to have a better understanding of their challenges, physical problems, and agreement on approaches for changing the built form of their neighborhoods. The questionnaires have been prepared based on information gathered through the secondary data and interview. The Likert scale has been used to rank the agreement of respondents on approaches for changing the built form of their neighborhoods. Likert scale is a psychometric response scale in the questionnaire to obtain the respondent's preferences or degree of agreement and disagreement with a statement [25]. On Likert scales, the participants are given the options to indicate their level of agreement or disagreement with a specific statement by way of an ordinal scale [25]. The Likert scale mostly occurs in 5 points scale, which includes the strong 
agree, agree, neutral, disagree, and strongly disagree. However, the variable of the Likert scale relates to the aim of the research, and some researchers want to ensure the validity and reliability of the research and use the 7 and 9 points scale, and some researchers use 3 points scale. However, 5 points scale is the most prevalent rating on the Likert scale [25]. Therefore, in this research, the 5 points Likert scale has been used.

Following the data collection, the gathered data have been taken under the process of examining, summarizing, and drawing conclusion The data analysis includes two steps, qualitative data analysis (interview) and quantitative data analysis (questionnaire survey).

The qualitative data analysis includes the analysis of the data, which has been obtained through the interview. In the interview, the data has been collected in the form of notes, Word texts, and transcripts, which include the description and explanation of distributed open-ended questions. This analysis aims to extract relevant information from the gathered data. Two approaches can be used to analyze the qualitative data, which are the deductive approach and the inductive approach [27]. The deductive approach includes using the predetermined framework to analyze the data, and the researchers use their structure on the gathered data to analyze the interview transcript $[27,28]$.

In contrast, the inductive approach contains analyzing of the data without predetermined theory and structure. This approach is suitable where a little is known about the study phenomenon, and this approach is the most common method for the qualitative data analysis [27,28]. Different of inductive approaches are available to analyze the qualitative data, but the most common is the content analysis and narrative analysis [27]. However, for this research, content analysis has been used. The content analysis includes different steps such as getting familiar with the data, coding and labeling the transcript, creation of categories (themes) by bringing several codes together, defining and naming the themes, and writing up the result [27]. In this research, first, the interview transcript has been read carefully, the informal settlement relevant words, sentences, phrases, and sections have been labeled and coded. The coded and labeled data which is relevant to the approaches to addressing the informal settlement problems have been highlighted.

The quantities data analysis includes the analysis of the data, which has been obtained through the survey questionnaires. In qualitative data analysis, the data analyses statistically [25]. This analysis aims to measure the resident's agreement on approaches for changing the built form of their neighborhoods in District 13 of Kabul city. In this research, Frequency Analyzes has been to analyses quantitative data. The results have tabulated in the form of frequency number and percentage according to the total respondents. Following that, the finding has been shown in the diagram for better understanding. The formula for the Frequency analysis is as:

$$
\text { Percentage }(\%)=\frac{\mathrm{n}}{\mathrm{N}} * 100 \%
$$

Equitation (1) is Frequency Analysis equation.

$\mathrm{n}=$ is the number of respondents which respond the same answer toward statement $\mathrm{N}=$ is the total number of respondents who have been participated in the research

Conclusion and recommendation is the last stage of this research, the framework of solution and recommendation according to finding and results have been suggested on improving informal settlement in District 13 of Kabul city. 


\section{Study Area}

Afghanistan located in Central Asia, which is a landlocked and mountain country, Afghanistan includes an area of $652000 \mathrm{~km} 2$. Afghanistan shares a border with Iran in the West, Pakistan, in East and South and Central Asian countries such as Tajikistan, Uzbekistan, and Turkmenistan in the North. Afghanistan is the 41st largest country in term of land areas. Afghanistan has 34 provinces, and each province divided into cities, districts, and villages. $[29,30]$.

Kabul city, which is the capital of Afghanistan located in Kabul province, known as the largest city of Afghanistan. Kabul Municipality Areas includes 22 Districts, with areas of 103049 Hectares with the almost 396095 dwellings [31,32]. Districts 13 of located to western part of Kabul city, the District 13th Western side makes the whole Kabul city boundary, in Southward it extends to the mountain areas also constitutes the city boundary, the North part of it the District 5 located and in the East part of it the District 6 located [33]. Figure 1 shows Kabul Metropolitan Areas.

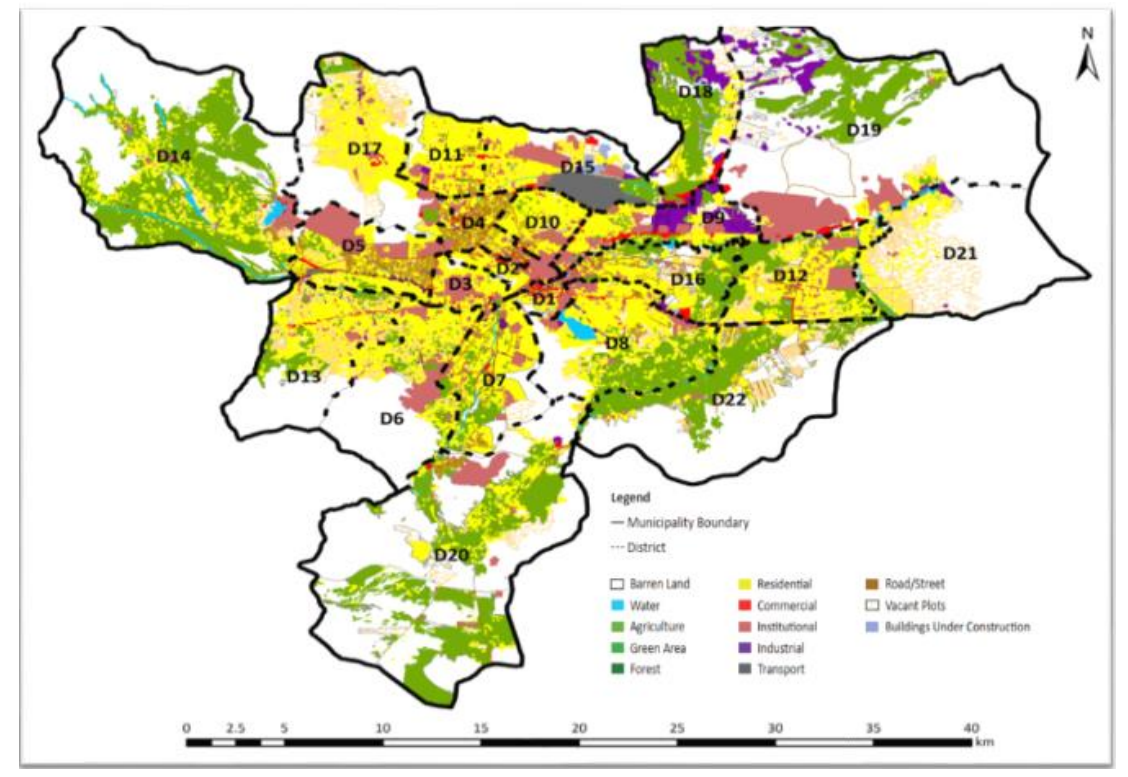

Figure 1: Kabul Metropolitan Areas. Source: [34].

\section{Result}

This section of research presents the finding and results which have been obtained through interview and survey questionnaire.

\subsection{Key Finding of Interview}

The critical finding of the interview includes approaches to addressing informal settlement problems in District 13 of Kabul city. In term of approaches for improvement of informal settlement since the entire District 13 developed informally. Most of the interviewees believe that it is not applicable to redevelop informal sentiments through the total clearance of informal settlements. For example, interviewee 1 (Table 1) indicates that "there are different approaches for the improvement of informal settlement, but it is important that the approaches should answer the needs and necessities of area. Then, land readjustment and urban redevelopment can perform a vital role in the improvement of informal settlement in District 13. Moreover, the settlement 
upgrading also has an important role in the improvement of informal settlement according to District 13 physical condition".

Interviewee 3 indicates that "the Kabul municipality implements two approaches to address the problems of informal settlements, settlement upgrading, and land readjustment projects. Based on the fiscal year work, Kabul municipality upgrades unplanned areas in Kabul city. Also, the land readjustment approach is ongoing only in Kabul city supported by JICA (Japan). Besides, settlement upgrading is the other approach that can be used for the improvement of District 13. Ministry of Urban Development and Land is a policymaker authority, which covers all cities around Afghanistan, Upgrading of Unplanned Settlement Directorate is preparing the policy and put the implementation of policy on the stand of respective municipalities".

Based on Interviewee 4 "for improvement of District 13, the Urban Authority can adopt the two-track strategy. First, preventive, not allowing other construction and housing development. Second lucrative, using redevelopment project by land readjustment, and urban redevelopment and housing progress."

Interviewee 10 indicates that "upgrading through different international organizations like UN-habitat and World Bank implemented for the improvement of the informal settlement in Kabul city. This usually does not bring much changes in the structure of a neighborhood, since it just includes improvement of the basic infrastructure like paving the streets and providing the drainage system. Most of the residents were satisfied with the upgrading approach, however in some informal areas, upgrading may not be applicable, or it will not bring much changes. Therefore, it was recommended that those areas should be improved through other development approaches, like land readjustment and urban redevelopment."

Interviewee 11 states that "when the development agency is preparing the improvement plans. The participation of the community should be considered to get knowledge about the people who live at the site. It is important to involve communities, to make a successful improvement plan, and to understand their needs."

According to interviewee 12 "Un-Habitat working on the upgrading of the areas with high population density and the areas where the poor residents live. This upgrading includes the paving of the street, the development of the drainage system and sewage system. The upgrading aims to increase, sense of belonging among people and the relationship between people and government by community involvement in the implementation of the projects".

Based on interviewee 14 "Land readjustment, urban redevelopment, and upgrading currently, have been taking in to account for the improvement of District 13. In addition, along the Qorogh mountain, if the site be considered for resettlement, it will help to reduce the problem of the informal settlement in District 13."

Most interviewees indicate that the land tenure problems and physical problems of the informal settlement must be addressed at the same time and parallel. Therefore, for the legalization of informal settlement, a Regulation on Registration of Urban Informal Properties prepared by Land Independent Authority and approved by the Afghanistan Cabinet in December 2017. Moreover, concluding form the interview, for addressing the physical problems of informal settlement, there are three approaches. First upgrading informal settlement with-stand of Ministry of Urban Development and Land, second land readjustment with-stand of Kabul Municipality, and third urban redevelopment with-stand of Kabul Municipality. To have a better understanding of the Regulation mentioned above and approaches, government policy is needed to be reviewed. 
In the end, it is going to be mentioned that the Ministry of Urban Development and Housing and Land Independent Authority of Afghanistan recently merge by the name of Ministry of Urban Development and Land.

\subsection{Policy Review in Addressing Land Tenure Issue}

For addressing the land tenure issue in Kabul city, Land Independent Authority prepared Regulation on Registration of Urban Informal Properties which has been approved by Afghanistan Cabinet in December 2017. Article 1 of this Regulation indicates that this Regulation is based on Article 112 of the Land Management Law. Article 112 of the Land Management Law indicates that "Matters relating to the provision of security of tenure for individuals residing on informal urban land. Including the survey and registration of the land and the issuance of documentation to individuals residing on the land shall be regulated by the Afghanistan Independent Land Authority with cooperation from the Kabul Municipality, and other respective municipalities and agencies in accordance with a separate Regulation [35]."

Based on Article 2 of this Regulation [35] "the main objective of this Regulation is to administrate the land survey process and registration of properties in the informal urban settlement. Furthermore, providing tenure security for the occupants of properties in informal urban settlement". Based on Article 4 of this Regulation [35] "Arazi (Land Independent Authority) is responsible for the implementation of this Regulation in cooperation with other relevant public agencies." Article 5 of this Regulation [35] indicates that the Arazi (Land Independent Authority) in collaboration with Ministry of Urban Development and Housing, Independent Directorate for Local Governance and Municipalities will identify the residential houses which are built in the informal settlements for registration and granting of occupancy certificates to the occupants according to the following conditions:

1. The property should be within the boundaries of the master plan and urban strategic plan.

2. The property should not locate within a water source area.

3. The property should not locate in public service establishments, entertainment parks, sports grounds, green areas, and protectable area.

4. The property should not be in an area that is planned for the development of government or public projects within a period of ten years.

For the registration and granting of property deeds, Article 8 of this Regulation [35] indicates that:

1. Arazi (Land independent Authority) shall register the residential houses, business places, public service establishments, empty land parcels, and protected areas located within the boundary of informal settlements.

2. Occupancy certificates will be granted only to occupants of residential houses in informal settlements.

3. The occupancy certificates mentioned above will be granted based on the following terms. The occupant should be a real person. The building should be used only for residential and shelter purposes. There is no conflict among the shareholders and descendants of the property. 
4. If there is a conflict involving the property, the property will be registered after solving the conflict.

If the residential house developed on governmental or state land and the property is occupying state land. Article 9 of this Regulation [35] addresses this issue as the following:

1. If a property in an informal settlement is on state land. Only $300 \mathrm{~m} 2$ will be registered in the name of the occupant or his/her descendant.

2. If a property in an informal settlement is on state land, any additional area from 300 $\mathrm{m} 2$ up to $500 \mathrm{~m} 2$ that is not required by the state can be sold to the occupant based on a just and fair price considering the location of the land.

3. If a property in an informal settlement is on state land, any additional area from 500 $\mathrm{m} 2$ up to $1000 \mathrm{~m} 2$ that is not required by the state can be sold to the occupant at the prevailing market price and considering the location of the land.

4. If a property in an informal settlement is on state land, any additional area exceeding $1000 \mathrm{~m} 2$ will be repossessed by the state from the occupant or his/her descendants.

In term of registration and issuing of the occupancy certificate, based on Article 11 of this Regulation [35]:

1. The occupancy certificate issues at the price of 1000 Afs (Afghanis currency) for the property occupants (man or woman).

2. Arazi (Land Independent Authority) will register and save the occupancy certificate, which contains all information on the characteristics of the property in a database.

3. The occupancy certificate prepares in three copies, one belonging to the occupant, the second one to the municipal district office, and the third one to the Arazi (Land Independent Authority) office.

4. The municipal district office is responsible for sending a copy of the occupancy certificate mentioned in section 3 to the municipality.

Preparation of the occupancy certificate is the responsibility of Arazi (Land independent Authority). Article 17 of the Regulation indicates that "the Arazi (Land independent Authority) will prepare the form and contents of the occupancy certificates. In addition, Arazi (Land independent Authority) and other relevant agencies must conduct public awareness campaigns for the occupants of informal settlements through radio, television, and other mass media". After issuing the occupancy certificate, Arazi (Land independent Authority) will sign a contract with the occupants of informal urban settlements. The contract will specify the responsibilities of the occupants. According to article 10 of the Regulation, the owner of an occupancy certificate must pay the annual Safayi (Clearance) fees to the municipality's bank account.

District 13 of Kabul city located within the boundary of the Kabul Master Plan. 70\% of the respondents responded that they have their own houses and are the owners of the houses where they live. And 30\% of respondents indicated that they rented the houses where they live. According to Article 8 of the Regulation on Registration of Urban Informal Properties, the occupancy certificate will be granted only to occupants of residential houses in informal settlements. Then, occupants of property who live in District 13 are eligible to apply for the occupancy certificate. And residents of District 13 who rent the houses are not eligible to apply for an occupancy certificate. The solution is that property owners of the rented houses 
apply for the occupancy certificate. Figure 2 shows the housing ownership in District 13 of Kabul city.

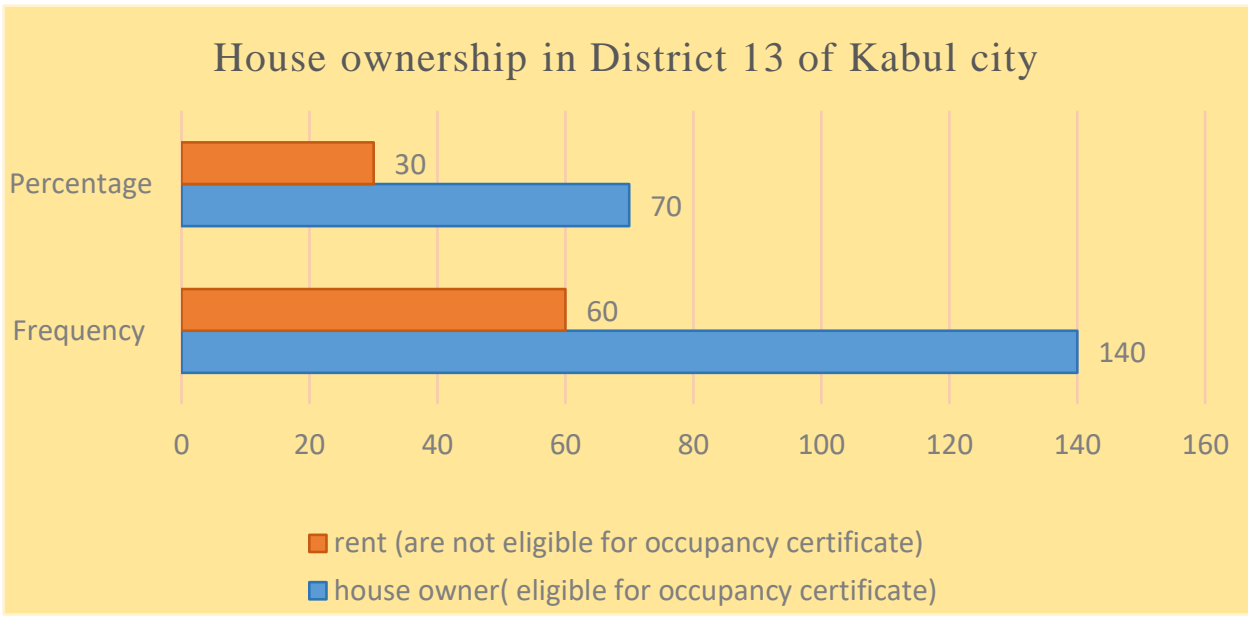

Figure 2. Housing ownership in District 13 of Kabul city. Source: Filed survey.

Moreover, to capitalize on the great planned, well-financed urbanization, the Government of Afghanistan, with technical assistance from UN-Habitat, is implementing an innovative program to address urban governance in Kabul and other eleven cities under the name of City for All. Based on interview with member of Un-Habitat, the City for All programmer is supporting Afghan municipalities to survey and register all properties (estimated 500000 properties in Kabul and 500000 properties in other eleven cities) within their boundaries to provide technical assistance to Arazi (Land Independent Authority) to issue occupancy certificate in informal urban areas to enhance tenure security for urban residents. According to City for All program, the households in Kabul city, including District 13, will receive an occupancy certificate guaranteeing their right to stay on their property without the threat of eviction. The legal framework for City for All program is Regulation on Registration of Urban Informal Properties. Therefore, by this Regulation and City for All Program, the land tenure issue addresses in District 13 of Kabul city.

\subsection{Policy Review in Addressing Physical Problems.}

There are three approaches to addressing the physical problems of the informal settlement in Kabul city, including the land readjustment and urban redevelopment withstand of Kabul Municipality, and settlement upgrading with-stand of Ministry of Urban Development and Land. Based on interviewee 1 (Table 1) the Ministry of Urban Development and Land is a policymaker authority, which covers all cities around Afghanistan. Upgrading of Unplanned Settlement Directorate is preparing the policy and put the implementation on the stand of respective municipalities. In addition to the Ministry of Urban Development and land and Kabul Municipality, Capital Region Independent Authority is in charge of providing the public facilities for the capital region of Afghanistan.

\subsubsection{Land Readjustment}

Based on the interview with the officials from Kabul Municipality, the land readjustment is using to re-shape and re-assemble the land parcel in Kabul city. According to land readjustment by the participation of people, the public facilities and basic services create 
in the urban areas, or the existing facilities will improve to increase the utility of the urban areas. To plan and implement the land readjustment project in Kabul city, Kabul Municipality prepared the Procedure on Land Readjustment and Urban Redevelopment and approved by Afghans Cabinet on 8 February 2017 [Interviewee 4,5].

The land contribution rate is based on required land for the provision of public amenities, recreation areas, widening of the streets, bank land, and financial land. The maximum rate of contribution is not exceeding $40 \%$ of the size of the housing plot. The owners of properties are required to contribute the required land for the provision of infrastructure and public amenities through the contribution rate [36].

Financial land is the specific land that will deduct from the contributed land to finance the project and services costs, and bank land is the storage and accumulation of land plots during the land readjustment process. The Municipality can sell it to finance the expansion expenditure of the project or can use for urban expansion and urban development later, and the bank land is $10 \%$ of total areas [36].

\subsubsection{Urban Redevelopment}

Based on the interview with the official from Kabul Municipality urban redevelopment project includes the conversion of the property right from land to the apartment with consideration of the land value and land location. In this case, selling the number of apartments provides the budget and project cost, including apartment construction cost, basic services cost, and other requirements of the project [36]. Urban redevelopment project can be implemented on the property with the following condition [36]:

1. In the master plan, the target area considered with medium and high population density.

2. The property located in areas where the public buildings and streets are considered to develop. Then, for the owners of the property in suitable areas, the apartments build to exchange the property to an apartment

Urban redevelopment in Kabul city includes the conversion of $40-70 \%$ of the property to apartment according to valuation and location of each property and its measurement to conversion to the apartment with agreement and consent of property owners and Kabul Municipality [36]. The remaining land will be sold to finance apartment construction cost, basic services cost, and other requirements of the project. If the converted land is smaller than the apartment areas, then the property owners are required to buy the remaining area of the apartment according to the Municipality's price of consideration. If the converted land is more than the one apartment or several apartment areas, in this case, the additional land according to Municipality's price of consideration with the agreement of landowners will be sold to pay for the landowner.

In the urban redevelopment process, temporary and permanent resettlement is an inevitable action. Besides, in urban redevelopment planning, the Kabul Municipality efforts to keep the residents in existing areas, by using the barren land for construction of new residential apartments. In the case of temporary resettlement, the following two alternatives are available for Kabul Municipality to settle the displaced residents up to the completion of the project. First, transfer of residents to residential buildings, which are the property of Kabul Municipality or the residential buildings, which are the property of the Afghan government 
and coordinated by Kabul Municipality. Second, receiving the funds from the Ministry of Finance by the Municipality to hire or rent residential houses in the area inside the city for displaced people by taking into consideration the life quality of the residents.

\subsubsection{Settlement Upgrading}

Upgrading of the urban area is a multi-sectoral operation that integrates environmental, economic, and social intervention. These interventions include the provision of urban services and the grantee of land tenure. To manage the settlement upgrading, the Ministry of Urban Planning and Land prepared the Policy on Upgrading and Redevelopment of informal settlement [interviwee2,4]. This Policy on the Upgrading of Informal Settlements is responding to Article 14 of the Afghanistan Constitution, which indicates: "the state shall adopt necessary measures for provision of housing and distribution of public estates to deserving citizens in accordance with the provisions of law and within financial possibilities."

Based on the interviewees from the Ministry of Urban Development and Land by taking into consideration the high percentage of the informal settlement in Afghanistan, particularly in Kabul city, it is not feasible to relocate and redevelop them through complete clearance. Thus a practical solution would be to regularize and upgrade these settlements in a systematic manner and convert them into the formal urban fabric. The Policy on Upgrading of Informal Settlement aims to provide a framework and policy guidance to integrate informal settlement as part of the urban fabric. The main objective and aims of the policy are [37]:

1. To enable the delivery and extension of urban services in all informal settlements in Afghanistan,

2. To promote the incremental improvement of tenure security along the continuum of property rights,

3. To enhance and increase municipal revenue and levies through the delivery of basic services to the informal urban settlements,

4. To regularize informal urban settlements in an orderly manner.

The government of the Islamic Republic of Afghanistan, implements and supervises the settlement upgrading through the Ministry of Urban Development and Land, the Independent Directorate for Local Government, and Municipalities. The Afghan government has established Urban Upgrading Directorate within the Ministry of Urban Development and Land to manage the settlement upgrading. In addition, Upgrading Directorate is responsible for coordinating between the Ministry and other relevant entities on settlement upgrading. The government of Afghanistan will assign resources from its development budget or seek external resources to upgrade informal settlement [Interviewee 1]. Furthermore, Based on Policy on Upgrading of Informal Settlement [37] that the following settlements have the settlement upgrading eligibility:

1. All settlements which are recognized eligible for occupancy certificate through Regulation on Registration of Urban Informal Properties.

2. Older unplanned settlements, such as urban villages.

3. Grabbed private land is not eligible for upgrading until the courts resolve the property status to clear title. 
4. If a building or area is designated as a historic building by the Ministry of Information Culture. Upgrading design in consultation with that Ministry, and they will have the authority to limit upgrading procedures that may damage cultural resources.

\subsection{Key Finding of Questionnaire Survey}

For the implementation of the land readjustment and land rearrangement in settlement upgrading, the landowners are required to distribute part of their land. Thus, this research aims to identify the agreement of the landowners on land distribution for the improvement of their settlements.

Figure 2 shows that $30 \%$ of the respondents are not the owner of the property. Then, they do not have the authority of land distribution. From $70 \%$ of the respondents who are the owners of the property, $8.5 \%$ of them disagree on land distribution, and $91.5 \%$ of them agreed on land distribution. Figure 3 shows the agreement of residents on land distribution.

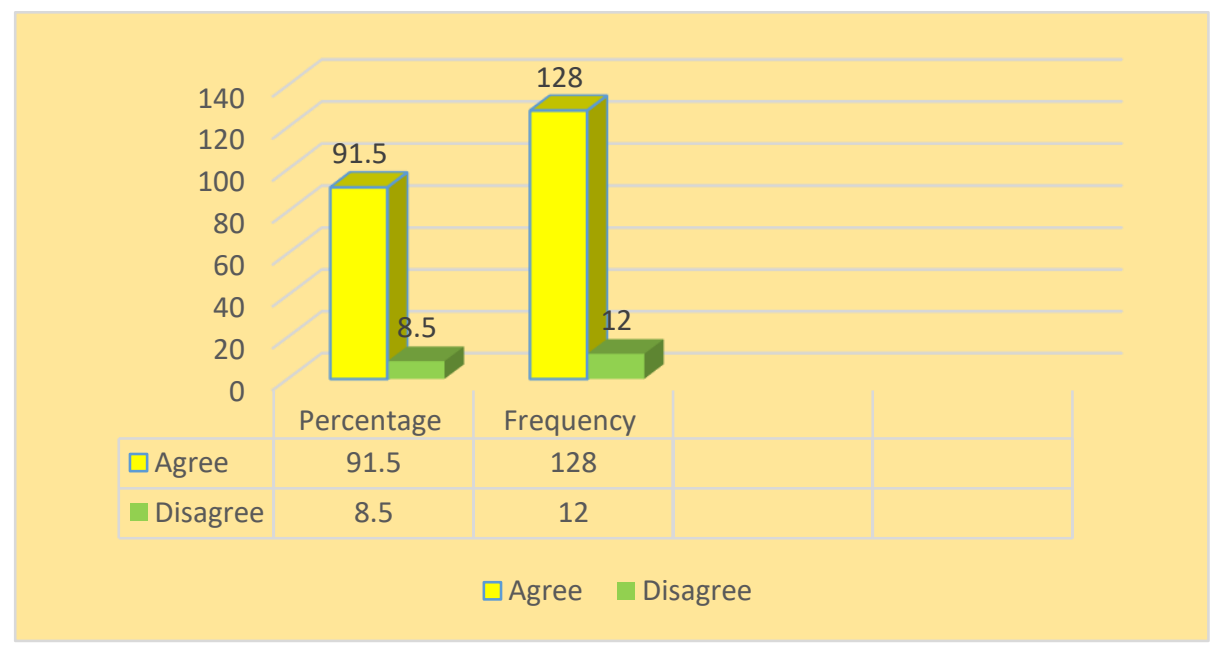

Figure 3. Agreement of residents on land distribution. Source: Filed survey.

Based on the interview, it has been found that there are three approaches (urban redevelopment, land readjustment, and settlement upgrading) to improve informal settlement in Kabul city. However, this research aims to examine these approaches from the perception of the residents of District 13. Table 2 shows the preferences of residents on approaches for improvement of the informal settlement in District 13 of Kabul city.

Table 2. Preferences of residents on approaches for improvement of informal settlement in District 13 of Kabul city.

\begin{tabular}{|c|c|c|c|c|c|c|}
\hline \multirow[t]{2}{*}{ No } & \multirow[t]{2}{*}{ Approaches } & \multicolumn{5}{|c|}{ Likert Scale } \\
\hline & & $\begin{array}{l}\text { Strong } \\
\text { agree }\end{array}$ & Agree & Neutral & Disagree & $\begin{array}{l}\text { Strong } \\
\text { disagree }\end{array}$ \\
\hline \multirow[t]{2}{*}{1} & \multirow[t]{2}{*}{ Settlement upgrading } & 113 & 69 & 7 & 11 & 0 \\
\hline & & $56.5 \%$ & $34.5 \%$ & $3.5 \%$ & $6.5 \%$ & $0 \%$ \\
\hline \multirow[t]{2}{*}{2} & \multirow[t]{2}{*}{ Land readjustment } & 71 & 90 & 12 & 17 & 10 \\
\hline & & $35.5 \%$ & $45 \%$ & $6 \%$ & $8.5 \%$ & $5 \%$ \\
\hline \multirow[t]{2}{*}{3} & \multirow[t]{2}{*}{ Urban redevelopment } & 31 & 44 & 21 & 88 & 16 \\
\hline & & $15.5 \%$ & $22 \%$ & $10.5 \%$ & $44 \%$ & $8 \%$ \\
\hline
\end{tabular}


Table 2 shows that $56.5 \%$ of the respondents strongly agree with the settlement upgrading, and $34.5 \%$ of the respondents agree with the settlement upgrading. Besides, $35.5 \%$ of the respondents strongly agree with the land readjustment, and $45 \%$ of the respondents agree with the land readjustment. On the other hand, $44 \%$ of the respondents disagree with the urban redevelopment approach, and $8 \%$ of the respondents strongly disagree with the urban redevelopment approach. Therefore, based on the perception of residents the settlement upgrading and land readjustment are the proper approaches to improve the informal settlement in District 13 of Kabul city.

\section{Discussion}

Three approaches can improve the informal settlement in District 13 of Kabul city. Firstly, settlement upgrading is one of the approaches that can improve the informal settlements in District 13 of Kabul city. Article 5 of Regulation on Registration of Urban Informal Properties indicates that the property locates within the boundary of the master plan is eligible to include in the upgrading program.

Because District 13 of Kabul city locates within the boundary of the master plan, thus, it is eligible for upgrading. Besides, the residents of District 13 prefer this approach for improvement of their settlement (Table 2). Moreover, it does not require land distribution, and its implementation is much more comfortable in contrast to the other two approaches. Also, it is not such a complicated approach, as a land readjustment approach, and also does not cost as an urban redevelopment approach. Thus, this approach can be the first option for improvement of the informal settlement in District 13 of Kabul city.

Second, land readjustment also can be one improvement approach for improvement of District 13, which is applicable within the boundary of the master plan of the Kabul city. Since the District 13 of Kabul city located within the boundary of the master plan apart from that $91.5 \%$ of the respondents agree to give part of their land for improvement of their settlements (Figure 3). Then, the land readjustment approach is applicable for the improvement of the informal settlement in District 13. However, this method requires government leadership to manage the land readjustment process and land distribution. Since the most influential factor behind the growth of informal settlement is the limited capacity of government [4]. Thus, this approach has its difficulties. Moreover, Table 2 shows in contrast to land readjustment, the residents of District 13 prefer the settlement upgrading approach. Then, the land readjustment approach can be the second option for the improvement of the informal settlement in District 13 of Kabul city.

Urban redevelopment is another approach to improve the informal settlement in District 13 of Kabul city. This approach is applicable in the areas with medium and high population density in the master plan. On the other hand, most proportions of District 13 considered as low population density areas in the master plan (See Figure 4). Thus, this approach is not applicable in the most proportion of District 13. Furthermore, Table 2 shows the majority of the respondents disagree with the urban redevelopment approach. However, during the filed survey, some respondents indicated that this approach could be the improvement approach for areas with low-quality housing, which will replace the low-quality houses with high-quality apartments. 
The low-quality houses located in a low population density area of District 13, on the other hand, this approach is implementable to the areas with high and medium population density. Moreover, this approach is costlier in contrast to the other two approaches. Although the conversion of land to the apartment finances the construction costs, but the construction of the apartment will take time. Besides, the municipality must provide settle for displaced people up to the project completion. It will add more cost to the urban redevelopment approach and requires good government leadership. Therefore, this approach can be the last option for the improvement of an informal settlement in District 13 of Kabul city. Figure 4 Kabul city Master Plan

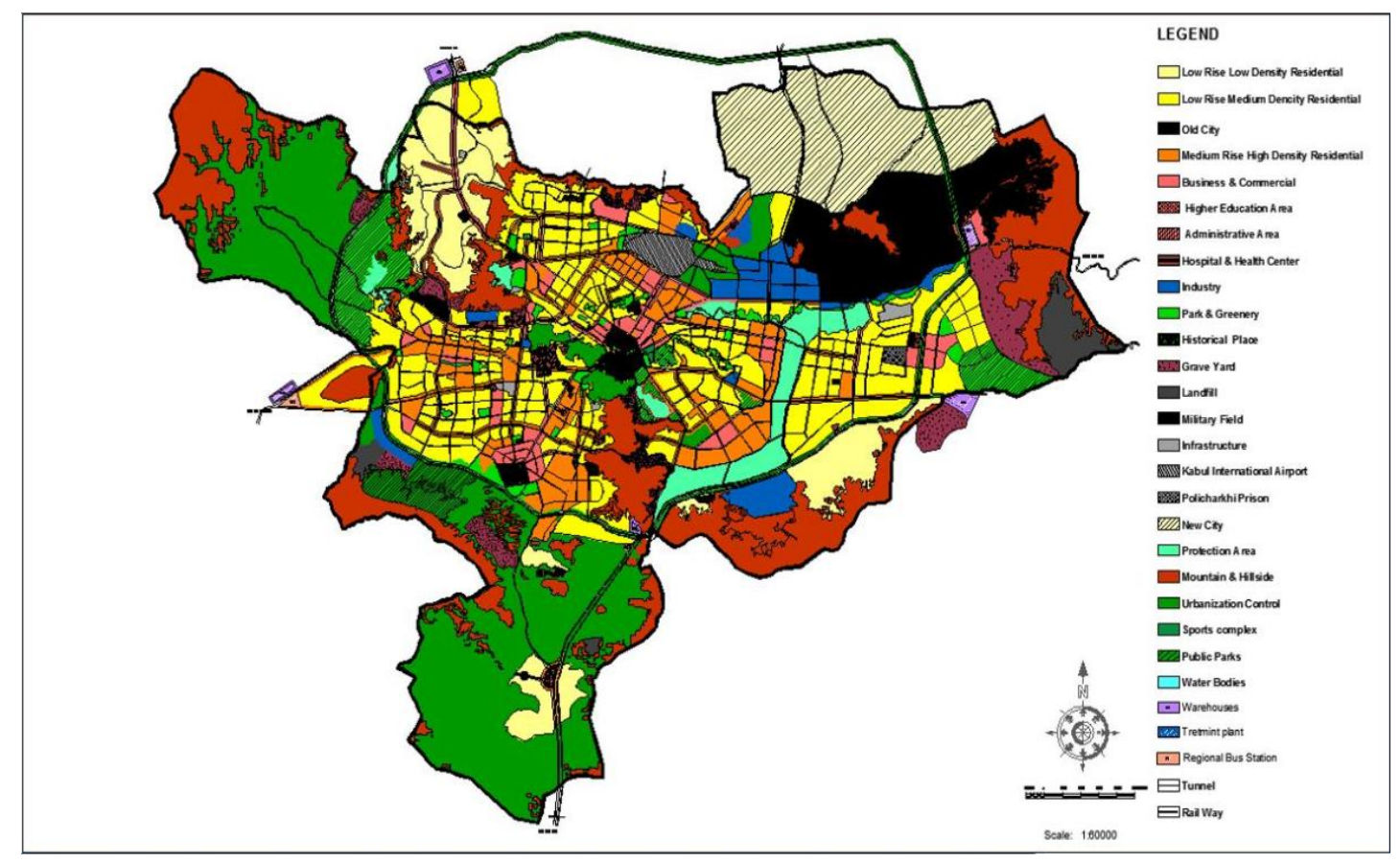

Figure4. Kabul city Master Plan. Source. [Field Survey].

The informal settlement differs in size and other characteristics from District to District, and this research has been done based on the perception of residents of District 13 of Kabul city (Kabul Municipality Areas includes 22 Districts). Thus, the finding of this research may not be implementable in other Districts of Kabul city. The study can be expanded to investigate other Districts of Kabul city.

In addition, for the implementation of each approach, the financial capacity of the Urban Authority is vital. The evaluation of the financial capacity of the Afghan Urban Authority missed in this research. Therefore, further research is needed to examine the financial capacity of the Afghan Urban Authority.

Moreover, to have a better understanding of the identification of the proper approach for improvement of informal settlements, it is crucial to have a better understanding of the needs, preferences, and demands of residents. Therefore, further research is needed to cover the needs and demands of residents. 


\section{Conclusion}

Afghanistan witnessed rapid urbanization in recent decades due to the post-war recovery process. When the war ended in 2001 by the fall of the Taliban regime, most Afghans refugees returned to urban areas of Afghanistan, especially in Kabul city. Moreover, the rapid urbanization, migration from rural areas, and population growth impacted on Kabul city with the manifestation of informal settlement [3]. Informal settlements are not without problems the physical problems of the informal settlement are considered enormous challenges for informal residents. Therefore, this paper investigates the approaches to addressing informal settlement problems.

The finding of this research to address the land tenure issue, the Regulation on Registration of Urban Informal Properties is the legal framework. Based on this Regulation Arazi (Land Independent Authority), in collaboration with the Ministry of Urban Development and Land, Independent Directorate for Local Governance and Municipalities will identify the residential houses which are built in the informal settlements for registration and granting of occupancy certificate which addresses the land tenure issue. On the other hand, three approaches can improve the informal settlement in District 13 of Kabul city. However, the finding of this research indicates that, according to the resident's preference and District 13 physical condition, settlement upgrading can be the first option, the land readjustment can be the second option, and urban redevelopment can be the last option.

This research will help the Afghan Urban Authority in choosing the proper approaches for improvement of District 13 according to its physical conditions and the preferences of residents. Besides, this research benefits the government by preventing further research on this matter. Furthermore, this research increases the awareness of residents towards their settlements, which will encourage them to feel more responsible for their environment and will encourage them to apply for an occupancy certificate.

However, this research is not without limitations. Firstly, the data has been gathered through survey questionnaires and interviews. Therefore, because of unwillingness, the respondents might respond to the questions without thinking quickly and incorrectly. Secondly, the residents of informal areas do not have secure land tenure, therefore, they may not respond honestly. Thirdly, the insecurity recently increased in the Districts 13 of Kabul city. It was a challenge for researchers to make the site visit. Finally, because the informal settlements differ in size and other characteristics from District to District. This research has been done based on the perception of residents of District 13 of Kabul city. Thus, this research may not be applicable in other Districts of Kabul city.

\section{Acknowledgments}

The work was financially supported by the Ministry of Education Malaysia and Universiti Teknologi Malaysia through the Research University Grant (GPU) Q. J130000.2652.16J54.

\section{Conflicts of Interest}

The authors declare no conflict of interest. 


\section{References}

1. Un-Habitat. Habitat III Issue Papers 22 -Informal Settlements; UN-Habitat: Nairobi, Kenya, 2015. Retrieved from: https://unhabitat.org/wp-content/uploads/2015/04/Habitat-III-Issue-Paper-22 InformalSettlements.pdf (accessed on 10 Sep 2018).

2. Abebe, F. K. Modeling informal settlement growth in Dar Es Salaam, Tanzania. M.Sc. Thesis, University of Twente, the Netherlands, 2011.

3. Bertaud, A. Urban Land Management in Afghanistan Kabul Urban Development Current city structure, spatial issues, recommendations on urban planning. Kabul Report 2 with graphs. Kabul Afghanistan, 2005.

Retrieved from:

http://alainbertaud.com/wpcontent/uploads/2013/06/AB_Kabul_Report_2-with graphs.pdf (accessed on 03 Sep 2018).

4. Bismill, R.A. Unperceptive Urban Growth: A case study on the growth of informal settlements of Kabul, Afghanistan. M.Sc. Thesis, University of Birmingham, Birmingham, 2014.

5. Nazire, H. A Study on Characteristics of Informal Settlements and Effects of Upgrading from Aspects of Houses, Land Acquisition, and Social Factors in Kabul City, Afghanistan. Ph.D. Thesis, Osaka University, Yamadaoka, Suita, Osaka, 2016.

6. Nazire, H.; Kita, M. Specifying Characteristics of Informal Settlements by Comparing Four Areas from the Aspects of Houses, Land Tenure and Social Factors in Kabul, Afghanistan. Journal of Architecture and Planning. 2016 81, 728, 2197-2206. https://doi.org/10.3130/aija.81.2197.

7. Fazli, M. Factors behind the Growth of Informal Settlements in Kabul. Institute of Urban and Spatial planning, Faulty of Architecture, the Slovak University of Technology Bratislava, (2016). DOI: 10.13164/ACAU.FA2016.9.

8. Javid, A. H. A Study on Cooperative Land Development by Landowners in Afghanistan's Context Considering Land Readjustment as Case Study. M.Sc. Thesis, University of Tokyo. Bunkyo, Tokyo, Japan 2013.

9. Gebremedhin, Y. Preliminary Assessment of Informal Settlements in Kabul City. Kabul, Afghanistan, 2005.

Retrieved from: http://www.terrainstitute.org/pdf/Informal_settlement_yohannes.pdf. (accessed on 11 May 2018).

10. Habib, J. Urban cohesiveness in Kabul City: challenges and threats. International Journal of Environmental Studies. 2011, 68,3, 363-371.

11. Ackelman, H.; Andersson, M. Methods to Solve the Problem of Informal Settlements, the Case of Hangberg, South Africa. M.Sc. Thesis, Royal Institute of Technology, Stockholm, Sweden 2008.

12. Choguill, C. L. The search for policies to support sustainable housing. Habitat International. 2007, 31, 143-149.

13. Nassar, D, M.; Elsayed H, G. From Informal Settlements to sustainable communities. Alexandria Engineering Journal. 2017, 57,4, 2367-2376.

14. Lombard, M. Constructing Ordinary Places: Place-Making in Urban Informal Settlements in Mexico. Progress in Planning. 2014, 94, 1-53. 
15. Khalifa, M. A. Evolution of Informal Settlements Upgrading Strategies in Egypt: From Negligence to Participatory Development. Ain Shams Engineering Journal. 2015, 6, 4, 11511159.

16. Nazire, H.; Kita, M.; Okyere, S. A.; Matsubara, S. Effects of Informal Settlement Upgrading in Kabul City, Afghanistan: A Case Study of Afshar Area. Journal of Architecture and Planning. 2016, 04, 04, 476-494. https://doi.org/10.3130/aija.81.2197.

17. Abbott, J. An analysis of informal settlement upgrading and critique of existing methodological approaches. Habitat International. 2002, 26, 303-315.

18. Burra, S. Towards a pro-poor framework for slum upgrading in Mumbai, India. Environment and Urbanization. 2005, 17, 1, 67-88.

19. Hegazy, I. R. Informal settlement upgrading policies in Egypt: towards improvement in the upgrading process. Journal of Urbanism. 2016, 9, 3, 254-275.

20. Erman, T. The politics of squatter (Gecekondu) studies in Turkey: the changing representation of rural migrant in the academic discourse. Urban Studies. 2001, 38, 7, 9831002.

21. Uzun, B., Çete, M.; Palancioglu, H. M. Legalizing and upgrading illegal settlements in Turkey. Habitat International. 2010 34, 204-209.

22. Okyere, A.S.; Kita, M. Rethinking urban informality and informal settlements growth in urban Africa: A literature discussion. Journal of Sustainable Development in Africa. 2015, 14, 6, 101-121.

23. Ranjbar, A. S.; Mizokami, S. Implementation of land readjustment process in Kabul Afghanistan. International Journal of Technical Research and Applications. 2015, 32, 32, 37-41.

24. Nagamine, H. The Land Readjustment techniques of Japan. Habitational. 1986, I0, 112, 5158.

25. Azila, H. Delay in settlement of final account. M.Sc. Thesis, Universiti Teknologi Malaysia, Skudai, Johor Bahru, Johor Malaysia, 2015.

26. Bird, D.K. The use of questionnaire for acquiring information on public perception of natural hazards and risks mitigation. Natural Hazards and Earth System Sciences. 2009, 9,4, 1307-1325.

27. Burnard, p.; Gill, p.; Stewart, K.; Treasure, E.; Chadwick B. Analyzing and presenting qualitative data. British Dental Journal. 2008, 204, 8, 429-432. DOI: 10.1038/sj.bdj.2008.292

28. Jamshid, S. Qualitative research method-interviewing and observation. Journal of Basic and Clinical Pharmacy. 2014, 5, 4, 87-88.

29. Nabizada, T. A Study on the Spatial Structure of Houses and Open Spaces by the Analysis of Physical Improvements and Daily Activities in the Typical Residential Areas in Kabul City. Ph.D. Thesis, Osaka University, Yamadaoka, Suita, Osaka 2012.

30. Ahmadi, A. S.; Kajita, Y. Evaluation of urban land development direction in Kabul city, Afghanistan. International Journal of Urban and Civil Engineering. 2017, 11, 2, 152-162.

31. JICA. Draft Kabul City Master Plan- Product of Technical Cooperation Project for Promotion of Kabul Metropolitan Area Development, Sub Project for Revise the Kabul City Master Plan. Kabul Afghanistan, 2011. Retrieved from: http://open jicareport.jica.go.jp/pdf/12058566 01.pdf (accessed on 23 Aug 2018).

32. JICA.; KM.; MUDH; DCDA. Promotion of Kabul Metropolitan Area Development: Capacity Development Project, Kabul City Current Status Report for Urban Development. Kabul, Afghanistan, 2011. Retrieved from: 
http://open jicareport.jica.go.jp/pdf/12068151.pdf (accessed on 14 Jun 2018).

33. MUDH.; KM.; IDLG. State of Afghan Cities. Kabul, Afghanistan, Volume 1, 2015. Retrieved:https://reliefweb.int/sites/reliefweb.int/files/resources/State\%20of\%20Afghan \%20Cities\%202015\%20Volume_1.pdf (accessed on 20 Jun 2018).

34. MUDH.; KM.; Un-Habitat. Strategic Nahia Action Plan, District 13. Kabul, Afghanistan, 2016

35. Regulation on Registration of Urban Informal Properties. Kabul, Afghanistan, 2017.

36. Procedure on Land Readjustment and Urban Redevelopment. Kabul Municipality. Kabul Afghanistan. 2017.

37. MUDH. Policy on Upgrading and Redevelopment of informal settlement. Kabul, Afghanistan, 2018. 